\title{
False positive results for antibody to HIV in two men with systemic lupus erythematosus
}

\author{
Maria H Esteva, Ana M Blasini, Dalhia Ogly, Martin A Rodriguez
}

\begin{abstract}
False positive results were obtained for HIV tests in two men with active systemic lupus erythematosus (SLE) who were suspected of being infected with HIV because of fever, weight loss, lymphadenopathy, and inflammatory myopathy. Enzyme linked immunosorbent assays (ELISAs) for HIV were twice positive when tested three times over a period of six months. Western blot analysis showed reactivity against the gp41 band in patient 1 . False positive results for HIV tests can occur in patients with SLE, potentially leading to an erroneous diagnosis of HIV infection.
\end{abstract}

(Ann Rheum Dis 1992; 51: 1071-1073)

Previous studies have addressed the potential role of infectious agents in the aetiopathogenesis of systemic lupus erythematosus (SLE). ${ }^{1}$ Common clinical and immunopathological features of HIV infection and autoimmune diseases $^{2}$ have renewed interest in examining the participation of this or a closely related agent in the aetiology of SLE. Antibodies to human $T$ cell leukaemia virus type $I$ have been reported in SLE by some workers ${ }^{3}$ but not others. ${ }^{4} 5$ Two previous reports have shown false positive results for antibodies to HIV in patients with SLE. ${ }^{6}$ The pathogenic significance of these antibodies in SLE remains to be established. Their presence may impede the diagnosis of coexisting HIV infection in patients with clinically active SLE. We here report two patients with active SLE and positive results for antibody to HIV by enzyme linked immunosorbent assay (ELISA) in whom HIV infection was suspected on clinical grounds but was unconfirmed by western blot analysis.

Centro Nacional

de Enfermedades

Reumatica,

Universidad Central

de Venezuela,

Hospital Universitario,

Caracas, Venezuela

M H Esteva

A M Blasini

M A Rodriguez

Instituto de Inmunologia, Universidad Central de Venezuela,

Hospital Universitario, Caracas, Venezuela D Ogly

Correspondence to: Dr M A Rodriguez, Centro Nacional de Enfermedades Reumaticas, Apartado 60681, Caracas 1060-A, Venezuela. Accepted for publication 13 May 1992
Laboratory tests showed haemoglobin $60 \mathrm{~g} / \mathrm{l}$, packed cell volume $0 \cdot 19$, white blood cell

count $5 \cdot 3 \times 10^{9} / 1$ with $18 \%$ lymphocytes, platelet

\section{Case reports}

A 30 year old male Hispanic college student with no history of intravenous drug abuse, blood transfusion, or high risk sexual behaviour had had fever, myalgias, dyspnoea, weight (about $5 \mathrm{~kg}$ ), mouth ulcers, and arthritis in his legs for four months before admission. Physical examination showed high blood pressure, diffuse lymphadenopathy, left pleural effusion, hepatomegaly, ascites, tibial oedema, synovitis in his knees and ankles, and symmetrical proximal muscle weakness. count $146 \times 10^{9} / 1$, and erythrocyte sedimentation rate (ESR) $100 \mathrm{~mm} /$ hour (Westergren). Blood chemistry was normal except for aspartate transaminase $233 \mathrm{U} / \mathrm{l}$, alanine transaminase 159 $\mathrm{U} / \mathrm{l}$, creatine kinase $240 \mathrm{U} / \mathrm{l}$, urea $69.6 \mathrm{mmol} / \mathrm{l}$, and serum creatinine $173 \mu \mathrm{mol} / \mathrm{l}$. Urine analysis showed 4+ proteins, red blood cells $20-40 /$ high power field and cellular casts. The 24 hour protein urinary excretion and the creatinine clearance were $4.13 \mathrm{~g}$ and $34 \mathrm{ml} /$ minute respectively. A percutaneous renal biopsy sample showed proliferative diffuse glomerulonephritis (class IV, WHO). Antinuclear antibodies and antibodies to DNA were positive at $4+$; the CH50 was <50 U/ml, C3 $189 \mathrm{mg} / 1, \mathrm{C} 480 \mathrm{mg} / \mathrm{l}$ and other autoantibodies were absent (table 1 ). Hepatitis anticore antibodies were positive and antibodies to $\mathrm{HBsAg}$ negative. IgM antibodies to cytomegalovirus were detected at $1 / 512$ dilution. Antibodies to HIV were twice positive by ELISA (DuPont Laboratories, Wilmington, DW, USA) at a one month interval. The western blot (DuPont Laboratories) analysis gave positive results for the gp4l band. The lymphocyte phenotypic profile was normal (table 1). Six months later the ELISA and western blot results were negative. The patient showed improvement of renal function with monthly intravenous pulses of cyclophosphamide and prednisone $60 \mathrm{mg} /$ day by mouth.

Table 1 Immunological features in patients with SLE with false positive results for antibody to HIV. Antibodies to HIV were detected by enzyme linked immunosorbent assay (ELISA) and western blot analysis

\begin{tabular}{|c|c|c|}
\hline Test & Patient 1 & Patient 2 \\
\hline $\begin{array}{l}\text { Antinuclear antibodies } \\
\text { Antibodies to DNA } \\
\text { CH50 } \\
\text { C3 } \\
\text { C4 } \\
\text { Antibodies to Sm } \\
\text { Antibodies to } \\
\text { ribonucleoprotein } \\
\text { Antibodies to SS-A } \\
\text { Antibodies to SS-B }\end{array}$ & $\begin{array}{l}4+(\text { speckled }) \\
4+ \\
\text { Low } \\
\text { Low } \\
\text { Low } \\
\text { Negative } \\
\text { Negative } \\
\text { Negative } \\
\text { Negative }\end{array}$ & $\begin{array}{l}4+\text { (diffuse) } \\
4+ \\
\text { Low } \\
\text { Low } \\
\text { Low } \\
\text { Negative } \\
\text { Negative } \\
\text { Negative } \\
\text { Negative }\end{array}$ \\
\hline $\begin{array}{l}\text { Lymphocyte subpopula } \\
\text { CD3 } \\
\text { CD4 } \\
\text { CD8 } \\
\text { CD16 } \\
\text { CD25 } \\
\text { Ig } \\
\text { HLA-DR } \\
\text { Monocyte/macrophage } \\
\text { HIV (ELISA) } \\
\text { HIV (western blot) }\end{array}$ & $\begin{array}{l}\text { n }(\%)^{*} \\
60.9 \text { (NS)t } \\
34.0 \text { (NS) } \\
24.3 \text { (NS) } \\
14.3 \text { (NS) } \\
3.8 \text { (NS) } \\
23.4 \text { (NS) } \\
18.9 \text { (NS) } \\
22.4 \text { (NS) } \\
\text { Positive } \\
\text { gp41 band }\end{array}$ & $\begin{aligned} & 21.6(\mathrm{p}<0.01) \dagger \\
& 4.2(\mathrm{p}<0.01) \\
& 8.4(\mathrm{p}<0.01) \\
& 2.4(\mathrm{p}<0.01) \\
& 11.9(\mathrm{NS}) \\
& 58.3(\mathrm{p}<0.01) \\
& 14.2(\mathrm{NS}) \\
& 16.4(\mathrm{p}<0.05) \\
& \text { Positive } \\
& \text { Negative }\end{aligned}$ \\
\hline
\end{tabular}

${ }^{*} 1 \times 10^{6}$ peripheral blood mononuclear cells were labelled with an optimum dilution of unconjugated or FITC conjugated monooptimum dilution of unconjugated or FITC conjugated monoclonal antibodies and proportions of positive cells were determined USA).

†Statistical analysis by unpaired Student's $t$ test comparing mean (SEM) $(\%)$ in patients and healthy subjects. NS=not significant. 
PATIENT 2

A 26 year old male Hispanic construction worker was diagnosed as having SLE in 1988 based on malar rash, photosensitivity, persistent leucopenia, and positive antibodies to DNA. He also developed sensitive polyneuropathy due to peripheral nerve vasculitis which was proved by taking a biopsy sample. He did not report a history of intravenous drug abuse, blood transfusion, or high risk sexual behaviour. He was being treated with prednisone $40 \mathrm{mg} /$ day and monthly intravenous cyclophosphamide. In 1989 he was treated for pulmonary tuberculosis. He was admitted to hospital in August 1990 with fever, abdominal pain, weight loss (about $6 \mathrm{~kg}$ ), myalgias, and proximal and distal muscle weakness. Physical examination showed a malar rash, diffuse alopecia, mouth ulcers, and white plaques in his mouth mucosae, enlarged lymph nodes, jaundice, and a tender hepatomegaly. In January 1991 he developed monarthritis of the right knee and secondary osteomyelitis due to Staphylococcus aureus coagulase positive infection. He showed an improvement after treatment with oxacillin, open drainage, and rehabilitation.

The laboratory tests showed haemoglobin $\mathbf{8 0}$ $\mathrm{g} / \mathrm{l}$, packed cell volume $0 \cdot 26$, white blood cell count, $3 \cdot 2 \times 10^{9} / 1$ with $12 \%$ lymphocytes, platelets $198 \times 10^{9} / 1$, aspartate transaminase $781 \mathrm{U} / \mathrm{l}$, and alanine transaminase $190 \mathrm{U} / 1$. Tests for hepatitis $A$ and $B$ were negative and a percutaneous liver biopsy sample showed diffuse hepatocellular damage and fibrosis. Antinuclear antibodies and antibodies to DNA were positive 4+, CH50 was <50 U/ml, C3 $370 \mathrm{mg} / \mathrm{l}$, and C4 $110 \mathrm{mg} / \mathrm{l}$; other autoantibodies were absent (table 1).

The patient tested positive twice for antibodies to HIV by ELISA with a two month interval, but was negative by Western blot analysis. Six months later both tests were negative. The lymphocyte phenotypic profile showed a marked decrease of CD3+ cells affecting both $\mathrm{CD} 4+$ and the $\mathrm{CD} 8+$ subpopulations. There was also enhanced expression of CD25 molecules of the interleukin 2 receptor and the number of CD16 + cells was significantly reduced. One year later the patient was well while receiving prednisone $15 \mathrm{mg} /$ day.

\section{Discussion}

These two cases illustrate the potential difficulties associated with diagnosing HIV infection in patients with SLE. The two types of disorder share clinical and immunological features such as skin rash, arthritis, lymphadenopathy, myositis, leucopenia, thrombocytopenia, hypergammaglobulinaemia, and high levels of circulating immune complexes. ${ }^{8}$ The appearance of low titres of antinuclear antibodies in patients infected with HIV raises further difficulties in the differential diagnosis.

Our patients had unequivocal SLE as they fulfilled six (patient 1) and seven (patient 2) American Rheumatism Association criteria ${ }^{9}$ (table 2) including high titres of antibodies to DNA and reduced serum complement levels. Both patients were men and presented with
Table 2 American Rheumatism Association (ARA) criteria for systemic lupus erythematosus present in patients with false positive results for antibody to HIV

\begin{tabular}{lll}
\hline Characteristic & Patient 1 & Patient 2 \\
\hline Age (years) & 30 & 26 \\
Sex & Male & Male \\
ARA criteria & & \\
Malar rash & Absent & Present \\
Photosensitivity & Absent & Present \\
Mouth ulcers & Present & Present \\
Arthritis & Present & Present \\
Serositis & Present & Absent \\
Renal disease & Present & Absent \\
Leukopenia & Absent & Present \\
Thrombocytopenia & Absent & Absent \\
Antinuclear antibodies & Present & Present \\
Antibodies to DNA & Present & Present \\
Antibodies to Sm & Absent & Absent \\
\hline
\end{tabular}

fever, significant weight loss, lymphadenopathy, and inflammatory myopathy, features that are common in patients infected with HIV. ${ }^{2}$

Serum samples from patient 1 were initially positive for the gp4l band in western blot analysis. The accepted international criteria require the presence of antibodies to p24, p31 and to gp4l and gpl20/gpl60 to confirm the diagnosis of HIV infection, however. ${ }^{10}$ In rare instances western blot tests can yield false positive results in healthy donors. False positive reactivity to band gp4l such as seen in our patients is exceptional in healthy subjects, however. ${ }^{11}$

Interestingly Golding et $a l^{12}$ showed cross reacting antibodies recognising the HIV gp41 protein and the $\beta 1$ domain of human major histocompatibility complex class II molecules in serum samples from patients with AIDs. Okudaira $e t a^{13}$ have reported the presence of antibodies to HLA-DR molecules in serum from patients with SLE. It is possible that serum samples from patient 1 had this pattern of cross reacting antibodies in the absence of HIV infection. Antibodies to the p24 gag protein of HIV-1 have also been reported in patients with SLE. ${ }^{14}$ Whether these antibodies arise by molecular mimicry to homologous host proteins or reflect viral infection remains to be established.

The diagnosis of HIV infection should always be considered in patients presenting with clinical symptoms suggestive of a systemic autoimmune disease. The use of rigorous confirmatory testing by western blot analysis or immunofluorescence assay is therefore mandatory. More sensitive assays such as gene amplification by the polymerase chain reaction may be necessary to confirm the presence of HIV infection in patients with unclear serological reactions.

Supported by grant S1-2349, Consejo Nacional de Investigaciones Cientificas y Tecnológicas (CONICIT).

1 Kalden J R, Winkler T, Krapf F. Are retroviruses involved in the aetiology of rheumatic diseases? $\mathrm{Br} \mathcal{F}$ Rheumatol 1991; 30: 63-9.

2 Winchester R. AIDS and rheumatic diseases. Bull Rheum Dis 1990; 39: 1-10.

3 Olsen R G, Tarr M J, Mathes L E, et al. Serological and virological evidence of human $T$ lymphotropic virus in SLE. Med Microbiol Immunol (Berl) 1987; 176: 53-64.

4 McDougal F S, Kennedy M S, Kalyanaraman V S, McDuffie F C. Failure to demonstrate (cross-reacting) antibodies to human lymphotropic viruses in patients with rheumatic diseases. Arthritis Rheum 1985; 41: 305-13.

5 Pelton B K, North M, Palmer M G, et al. A search for retrovirus infection in systemic lupus erythematosus and rheumatoid arthritis. Ann Rheum Dis 1988; 47: 206-9. 
6 Leo-Amador G E, Ramirez J M, Glavan F, Perla A V. Antibodies against human immunodeficiency virus in generalized lupus erythematosus. Salud Publica Mex 1990 32: 15-9.

7 Morales J, Moreno-Maldonado S, Hernandez C, Orozco $M$ E. Falsas positivas anti-HIV en lupus eritematoso sistemico. Reviews of Mexican Rheumatology 1988; 3 $114-7$.

8 Buskila D, Gladiman D. Musculoskeletal manifestations of infection with human immunodeficiency virus. Rev Infect Dis 1990; 12: 223-35.

9 Tan E M, Cohen A S, Fries J F, et al. The 1982 revised criteria for the classification of systemic lupus erythematosus. Arthritis Rheum 1982; 25: 1271-7.

10 The consortium for retrovirus serology standardization. Serological diagnosis of human immunodeficiency viru infection by Western blot testing. JAMA 1988; 260: 874-9.

11 Midthum K, Garrinson L, Clements M L, et al. Frequency of indetermined Western blot tests in healthy adults at low risk for human immunodeficiency virus infection. $\mathcal{F}$ Infect Dis 1990; 162: 1379-82.

12 Golding H, Robey F A, Gates F T III, et al. Identification of homologous regions in human immunodeficiency virus I gp4l and human class II $\beta 1$ domain. Monoclonal antibodies against the gp4l-derived peptide and patient's sera react with native HLA class II antigens, suggesting a role for autoimmunity in the pathogenesis of acquired immune deficiency syndrome. $\mathcal{F}$ Exp Med 1988; 167: 914-23.

13 Okudaira K, Searles R P, Ceuppens J L, Goodwin I S, Williams R C Jr. Anti-Ia reactivity in sera from patients with systemic lupus erythematosus. I Clin Invest 1982; 69: with sys

14 Talal N, Dauphinee M J, Dang H. A possible retroviral etiology for Sjögren's syndrome. In: Chahade W H, Giorgi R D, Hirose-Pastor E M, Sato E I, eds. Proceedings of the ILAR 89 Congress of Rheumatology, São Paulo, Brazil: Companhia Melhoramentos de São Paulo, 1989: 646-8. 